\title{
Studi Kontribusi Spirit At Work terhadap Komitmen Organisasi Guru Honorer X
}

\author{
Revia Eka Putri Mardianny *, Ali Mubarak \\ Prodi Psikologi, Fakultas Psikologi, Universitas Islam Bandung, Indonesia. \\ revia_via@yahoo.com, mubarakspsi@gmail.com
}

\begin{abstract}
Welfare and career certainty for honorary teachers in Indonesia is still unclear. However, they feel that their work gives them a positive meaning that keeps them in their profession as honorary teachers in the schools where they are teaching. The aim of this study is to determine the description and contribution of Spirit At Work (SAW) to organizational commitment of honorary teachers. This study is a contribution study with quantitative methods. Respondents in this study were all 40 honorary teachers of $\mathrm{X}$. The instrument used to measure SAW is the Spirit At Work Scale developed by Kinjerski and Skrypnek (2006), while Organizational Commitment Questionnaire developed by Allen \& Meyer (1990) used to measure organizational commitment, both were adapted by researcher. This study used Structural Equation Modeling (SEM) to analyze the data. The results of this study indicate that $95 \%$ of honorary teachers at $X$ have high SAW with most of the honorary teachers have the high AC, CC, and NC as their organizational commitment profile as much as $75 \%$. Then SAW has a positive and significant effect on AC $(0.000<0.05)$ by $42.5 \%, \mathrm{CC}$ $(0.000<0.05)$ by $23.8 \%$, and $\mathrm{NC}(0.000<0.05)$ by $22.1 \%$.
\end{abstract}

Keywords: Spirit At Work, Organizational Commitment, Honorary Teacher.

Abstrak. Kesejahteraan dan kepastian karier guru honorer di Indonesia masih tidak jelas. Namun demikian, mereka merasa bahwa pekerjaannya memberi mereka makna yang positif yang membuat mereka tetap menjalani profesi mereka sebagai guru honorer di sekolah tempat mereka mengajar. Tujuan dari penelitian ini adalah untuk mengetahui gambaran dan kontribusi antara Spirit At Work (SAW) terhadap komitmen organisasi pada guru honorer. Metode yang digunakan adalah studi kontribusi dengan metode kuantitatif. Responden dalam penelitian ini adalah seluruh guru honorer X sejumlah 40 orang. Alat ukur yang digunakan untuk mengukur variabel SAW adalah Spirit At Work Scale yang dikembangkan oleh Kinjerski dan Skrypnek (2006), sementara untuk mengukur variabel komitmen organisasi menggunakan Organizational Commitment Questionnaire yang dikembangkan oleh Allen \& Meyer (1990) yang keduanya diadaptasi oleh peneliti. Analisis data yang digunakan adalah Structural Equation Modelling (SEM). Hasil penelitian ini menunjukkan bahwa sebesar 95\% guru honorer X memiliki SAW yang tinggi dengan profil komitmen organisasi yang paling banyak dimiliki adalah $\mathrm{AC}, \mathrm{CC}$, dan $\mathrm{NC}$ yang seluruhnya tinggi sebanyak $75 \%$. Kemudian SAW berpengaruh secara positif dan signifikan terhadap AC $(0.000<0.05)$ sebesar $42.5 \%$, $\mathrm{CC}(0.000<0.05)$ sebesar $23.8 \%$, dan NC $(0.000<0.05)$ sebesar $22.1 \%$.

Kata Kunci: Spirit At Work, Komitmen Organisasi, Guru Honorer 


\section{A. Pendahuluan}

Guru honorer hadir untuk membantu kurangnya jumlah tenaga guru tetap (Ufaira \& Hendriani, 2020) di mana pekerjaan yang dilakukan oleh guru honorer sama seperti guru tetap, akan tetapi kesejahteraan dan kejelasan akan kariernya kurang diperhatikan. Penelitian mengenai guru honorer baru terdapat beberapa saja, seperti yang dilakukan oleh Gunawan \& Hendriani (2020) yang meneliti psychological well-being pada guru honorer di Indonesia dan penelitian yang dilakukan oleh Balkis \& Masykur (2016) yang meneliti subjective well-being guru honorer di sekolah dasar negeri. Di mana dari hasil penelitian tersebut didapatkan hasil bahwa para guru honorer merasakan perasaan positif dan merasa bahwa pekerjaannya memberi mereka banyak makna. Hal tersebut yang diindikasikan adanya spirit at work dalam diri para guru honorer tersebut.

Walaupun banyaknya sorotan dan pemberitaan mengenai kurangnya kesejahteraan guru honorer, tidak menyurutkan minat banyak orang untuk menjadi guru walaupun dengan status guru honorer. Seperti dilansir Jabar Ekspres pada tahun 2019, sesuai dengan data dari Dinas Pendidikan Kota Bandung mengungkapkan bahwa sejauh ini jumlah guru honorer jumlahnya lebih banyak daripada guru PNS dengan rincian guru PNS yang tercatat mengajar pada tingkat Paud, SD, dan SMP di Kota Bandung mencapai 7.287 orang, sedangkan pegawai non PNS mencapai 12.431 orang (jabarekspres.com, 2019). Perbandingan di mana jumlah guru honorer lebih banyak dibandingkan dengan jumlah guru PNS ini terjadi juga di salah satu sekolah menengah swasta di Kota Bandung, yaitu X.

Dari hasil wawancara yang dilakukan pada guru honorer di X didapatkan data bahwa mereka tetap bertahan bekerja sebagai guru honorer di organisasi tersebut karena merasakan adanya keselarasan nilai antara dirinya dan organisasi, gaji yang diterima lebih baik dibandingkan sekolah lain dan adanya rasa kebanggaan dapat bekerja di bawah yayasan besar, serta merupakan tuntutan untuk mengajar sebagai seorang guru. Hasil data tersebut menggambarkan indikasi adanya komitmen organisasi pada diri guru honorer tersebut. Menurut Meyer \& Allen (1991) menjelaskan bahwa komitmen merupakan keadaan psikologis yang (a) menggambarkan hubungan karyawan dengan organisasi, dan (b) memiliki implikasi terhadap keputusan untuk melanjutkan atau tidak melanjutkan keanggotaan di dalam organisasi. Salah satu hasil positif dari adanya komitmen organisasi pada guru ditandai dengan adanya tingkat turnover yang rendah dalam organisasi tersebut (Wahyuni, Suroso, \& Farid, 2019).

Selain itu, guru honorer di X menyatakan bahwa pekerjaan mereka sebagai guru itu memberikan mereka banyak hal positif, perasaan positif, dan memberikan mereka banyak makna. Gambaran dari data tersebut mengindikasikan adanya spirit at work pada diri guru honorer tersebut. Spiritualitas menjelaskan mengenai orang-orang yang merasakan keterhubungan antara satu orang dengan yang lainnya dan juga terhadap komunitas tempat kerja mereka (Ashmos \& Duchon, 2000).

Terdapat beberapa penelitian yang menjelaskan bagaimana hubungan antara spirit at work dengan komitmen organisasi. Penelitian yang dilakukan oleh Freund et al., (2016) menunjukkan bahwa spirit at work memiliki korelasi positif antara komitmen afektif, tetapi tidak terdapat korelasi yang signifikan antara spirit at work dengan komitmen kontinuans. Kemudian Pawar (2009) dalam Bell-Ellis, et al. (2015) mengidentifikasi asosiasi yang signifikan dan positif antara workplace spirituality dan komitmen organisasi. Kemudian Rego \& Cunha (2008) dalam Bell-Ellis, et al. (2015) mengemukakan bahwa karyawan yang merasakan workplace spirituality memiliki rasa attachment dan rasa memiliki terhadap organisasi yang lebih besar.

Tujuan dari penelitian ini adalah untuk mengetahui gambaran spirit at work pada guru honorer. Kemudian untuk mengetahui gambaran profil komitmen organisasi pada guru honorer. Yang terakhir untuk mengetahui kontribusi antara spirit at work terhadap komitmen afektif, kontinuans, dan normatif pada guru honorer.

\section{B. Metode Penelitian}




\section{Teori Spirit At Work}

Menurut Kinjerski \& Skrypnek (2004) menjelaskan bahwa "spirit at work" merupakan sebuah istilah yang menggambarkan pengalaman dari para karyawan yang tertarik dengan dan diberi energi oleh pekerjaan mereka, menemukan makna dan tujuan dalam pekerjaan mereka, merasakan bahwa mereka dapat mengekspresikan diri mereka seutuhnya di tempat kerja, dan merasakan keterhubungan dengan orang lain yang bekerja dengan mereka.

Terdapat empat dimensi spirit at work, yaitu:

1. Engaging work dikarakteristikkan oleh perasaan sejahtera yang mendalam, sebuah belief di mana seseorang terlibat dalam sebuah pekerjaan yang bermakna yang memiliki tujuan yang lebih tinggi dan sebuah kesadaran dari keselarasan antara nilainilai dan belief seseorang dan pekerjaan seseorang, serta perasaan menjadi autentik (Kinjerski \& Skrypnek, 2006).

2. Mystical experience merupakan sebuah rasa kesempurnaan dan transendensi. Dimensi ini dikarakterisasikan oleh sebuah kondisi energi atau vitalitas yang positif, perasaan sempurna, transendensi, serta merasakan suka dan duka. (Kinjerski \& Skrypnek, 2006).

3. Spiritual connection dikarakterisasikan oleh rasa keterhubungan dengan sesuatu yang lebih besar daripada dirinya sendiri (Kinjerski \& Skrypnek, 2006).

4. Sense of community digambarkan oleh perasaan keterhubungan dengan orang lain dan tujuan bersama (Kinjerski \& Skrypnek, 2006).

Spirit at work diukur menggunakan Spirit At Work Scales yang dikembangkan oleh Kinjerski \& Skrypnek (2006) yang terdiri atas atas 18 item pernyataan yang terbagi dalam empat dimensi spirit at work dengan skor jawaban yang bergerak dari skor 1 (Sangat Tidak Sesuai) sampai 6 (Sangat Sesuai).

\section{Teori Komitmen Organisasi}

Meyer \& Allen (1991) mengemukakan bahwa komitmen dikonseptualisasikan dalam tiga pendekatan, yaitu komitmen afektif, komitmen kontinuans, dan komitmen normatif. Yang umum terhadap ketiga pendekatan ini adalah pandangan bahwa komitmen merupakan sebuah keadaan psikologis yang (a) menggambarkan hubungan karyawan dengan organisasi, dan (b) memiliki implikasi terhadap keputusan untuk melanjutkan atau tidak melanjutkan keanggotaan di dalam organisasi.

Terdapat tiga aspek komitmen organisasi, yaitu:

1. Komitmen afektif merujuk pada kelekatan emosional karyawan terhadap, identifikasi dengan, dan keterlibatan dalam organisasi. Karyawan dengan komitmen afektif yang kuat melanjutkan pekerjaan mereka dengan organisasi karena mereka ingin melakukannya.

2. Komitmen kontinuans merujuk pada kesadaran akan biaya yang dikaitkan dengan meninggalkan organisasi. Karyawan yang hubungan utamanya dengan organisasi didasarkan pada komitmen kontinuans tetap bertahan karena mereka butuh untuk melakukannya.

3. Komitmen normatif merefleksikan perasaan dari kewajiban untuk melanjutkan pekerjaan. Karyawan dengan tingkat Komitmen normatif yang tinggi merasa bahwa mereka seharusnya bertahan dengan organisasi.

Komitmen organisasi diukur menggunakan Organizational Commitment Questionnaire yang dikembangkan oleh Allen \& Meyer (1990) yang terdiri atas 24 item yang masing-masing aspeknya terdiri atas delapan item Affective Commitment Scale items, Continuance Commitment Scale items, Normative Commitment Scale items dengan skor jawaban yang bergerak dari skor 1 (Sangat Tidak Sesuai) sampai 7 (Sangat Sesuai).

\section{Hasil dan Pembahasan Gambaran Spirit At Work Guru Honorer X}

Tabel 1. Persentase Pengkategorian Spirit At Work pada Guru Honorer X 


\begin{tabular}{lcc}
\hline Kategori & Frekuensi & Persentase \\
\hline Rendah & 2 & $5 \%$ \\
Tinggi & 38 & $95 \%$ \\
\hline Total & $\mathbf{4 0}$ & $\mathbf{1 0 0 \%}$ \\
\hline
\end{tabular}

Berdasarkan Tabel 3 didapatkan hasil bahwa sebanyak 5\% atau 2 orang guru honorer $\mathrm{X}$ memiliki spirit at work yang rendah dan $95 \%$ atau 38 orang guru honorer $\mathrm{X}$ memiliki spirit at work yang tinggi.

Dari pengujian yang telah dilakukan, dapat dilihat bahwa gambaran kondisi spirit at work pada para guru honorer X menunjukkan bahwa 95\% para guru honorer tersebut memiliki spirit at work yang tinggi. Seperti yang dijelaskan oleh Kinjerski \& Skrypnek (2006) bahwa orang yang memiliki spirit at work merupakan orang-orang yang dapat menyesuaikan dirinya dengan baik dan menunjukkan keharmonisan batin. Mereka memiliki energi yang positif, teliti, dan cenderung terbuka pada berbagai kemungkinan. Dengan hasil pengujian yang didapatkan dapat dikatakan bahwa hampir seluruh guru honorer $\mathrm{X}$ mampu untuk menyesuaikan dirinya dengan lingkungan bekerjanya, menunjukkan bahwa mereka memiliki kehidupan batin yang harmonis, memiliki energi yang positif, teliti, dan juga mau untuk terbuka dengan berbagai kemungkinan yang ada.

Sesuai dengan yang dikemukakan oleh Kinjerski (2004) dalam Kinjerski \& Skrypnek (2006) bahwa jika seseorang memiliki spirit at work yang tinggi, maka kesejahteraan individu tersebut akan meluap ke bagian kehidupan yang lainnya, memberikan efek positif pada hubungan dengan rekan kerja di tempat bekerja yang sama dengan dirinya, meningkatkan pelayanan konsumen di mana dalam hal ini guru honorer $\mathrm{X}$ akan meningkat dalam hal pelayanan untuk mengajar anak didiknya, meningkatkan produktivitas dalam hal kualitas dan kuantitas pekerjaan yang dihasilkan, dapat menurunkan absenteeism dan turnover, serta dapat meningkatkan kepuasan kerja dan komitmen.

\section{Gambaran Profil Komitmen Organisasi Guru Honorer X}

Tabel 2. Persentase Profil AC, CC, NC pada Guru Honorer X

\begin{tabular}{lcc}
\hline \multicolumn{1}{c}{ Profil } & Frek. & $\mathbf{\%}$ \\
\hline AC, CC, NC Tinggi & 30 & $75 \%$ \\
AC, CC, NC Rendah & 1 & $2.5 \%$ \\
AC Tinggi, CC Rendah, NC Rendah & 0 & $0 \%$ \\
AC Rendah, CC Tinggi, NC Rendah & 1 & $2.5 \%$ \\
AC Rendah, CC Tinggi, NC Tinggi & 1 & $2.5 \%$ \\
AC Rendah, CC Rendah, NC Tinggi & 3 & $7.5 \%$ \\
AC Tinggi, CC Tinggi, NC Rendah & 1 & $2.5 \%$ \\
AC Tinggi, CC Rendah, NC Tinggi & 3 & $7.5 \%$ \\
\hline Total & $\mathbf{4 0}$ & $\mathbf{1 0 0 \%}$ \\
\hline
\end{tabular}

Berdasarkan Tabel 2 didapatkan hasil bahwa sebanyak $75 \%$ atau 30 orang guru honorer X memiliki profil komitmen afektif, kontinuans, dan normatif yang tinggi, kemudian untuk profil komitmen afektif rendah, kontinuans rendah dan normatif tinggi, serta komitmen afektif tinggi, kontinuans rendah, dan normatif tinggi masing-masing sebanyak $7.5 \%$ atau 3 orang. Terdapat 4 profil yang masing-masingnya memiliki persentase $2.5 \%$ atau 1 orang yaitu profil komitmen afektif, kontinuans, dan normatif rendah, profil komitmen afektif rendah, kontinuans tinggi, dan normatif rendah, profil komitmen afektif rendah, kontinuans tinggi, dan normatif tinggi, dan profil komitmen afektif tinggi, kontinuans rendah, dan normatif rendah. Untuk profil komitmen afektif tinggi, kontinuans rendah, dan normatif rendah tidak ada guru honorer SMAS BPI 1 Bandung yang memilikinya.

Walaupun dimensi komitmen organisasi tersebut saling terpisah satu sama lainnya, tetapi sebenarnya setiap orang memiliki ketiga dimensi tersebut hanya saja dimensi mana yang lebih dominan pada orang tersebut. Dari hasil penelitian yang dilakukan, didapatkan hasil gambaran profil komitmen organisasi masing-masing guru honorer di X. Hasilnya 
menunjukkan bahwa sebagian besar guru honorer $\mathrm{X}$ memiliki profil komitmen afektif, kontinuans, dan normatif yang seluruhnya tinggi dengan persentasi sebanyak $75 \%$ atau 30 orang.

\section{Kontribusi Spirit At Work terhadap Komitmen Afektif, Kontinuans, dan Normatif Guru Honorer X}

Tabel 3. Hasil Uji Koefisien Determinasi ( $R$ Square)

\begin{tabular}{rrr}
\hline & R Square & R Square Adjusted \\
\hline AC & 0.425 & 0.409 \\
CC & 0.238 & 0.218 \\
NC & 0.221 & 0.200
\end{tabular}

Dilihat dari Tabel 3, $R$-square $\left(\mathrm{R}^{2}\right)$ konstruk dependen AC diperoleh adalah sebesar 0.425 , sehingga dapat dikatakan bahwa konstruk SAW berpengaruh terhadap AC sebesar 42.5\%, sedangkan sisanya sebesar $57.5 \%$ dipengaruhi oleh variabel lain di luar model penelitian ini.

Kemudian untuk $R$-square $\left(\mathrm{R}^{2}\right)$ konstruk dependen CC diperoleh nilai sebesar 0.238, sehingga dapat dikatakan bahwa konstruk SAW berpengaruh terhadap CC sebesar $23.8 \%$ dan sisanya sebesar $76.2 \%$ dipengaruhi oleh variabel lain di luar model.

Lalu yang terakhir hasil $R$-square $\left(\mathrm{R}^{2}\right)$ konstruk dependen $\mathrm{NC}$ diperoleh nilai sebesar 0.221 , sehingga dapat dikatakan bahwa konstruk SAW berpengaruh terhadap NC sebesar $22.1 \%$ dan sisanya sebesar $77.9 \%$ dipengaruhi oleh variabel lain di luar model.

Besarnya pengaruh antara spirit at work terhadap komitmen afektif adalah sebesar 0.425 atau $42.5 \%$, sementara sisanya sebesar $57.5 \%$ merupakan pengaruh dari variabel lain yang tidak diteliti. Kemudian didapatkan hasil bahwa spirit at work memiliki pengaruh positif dan signifikan terhadap komitmen kontinuans yang berarti semakin tinggi spirit at work yang dimiliki, maka semakin tinggi pula komitmen kontinuans yang miliki oleh guru honorer di $\mathrm{X}$ dan juga sebaliknya. Besarnya pengaruh antara spirit at work terhadap komitmen kontinuans adalah sebesar 0.238 atau $23.8 \%$, sementara sisanya sebesar $76.2 \%$ merupakan pengaruh dari variabel lain yang tidak diteliti. Lalu didapatkan hasil bahwa spirit at work memiliki pengaruh positif dan signifikan terhadap komitmen normatif yang artinya semakin tinggi spirit at work yang dimiliki, maka semakin tinggi pula komitmen normatif yang dimiliki oleh guru honorer di X tersebut dan juga sebaliknya. Besarnya pengaruh antara spirit at work terhadap komitmen normatif adalah sebesar 0.221 atau $22.1 \%$ sementara sisanya sebesar $77.9 \%$ lainnya merupakan pengaruh dari variabel lain yang tidak diteliti.

Dari yang telah dijelaskan di atas, bahwa sekitar 55\% sampai hampir $80 \%$ yang memengaruhi komitmen afektif, kontinuans, dan normatif merupakan variabel lain yang tidak diteliti. Diperkirakan variabel lain yang memengaruhi komitmen organisasi guru honorer $\mathrm{X}$ sesuai dengan penelitian-penelitian sebelumnya yang telah dilakukan antara lain masa kerja (Seniati, 2010; Yusnita, 2015), kepuasan kerja (Seniati, 2010; Yusnita, 2015), trait kindness (Seniati, 2010), karakteristik pribadi (kebutuhan untuk berprestasi, usia, pendidikan), karakteristik pekerjaan (identitas tugas, interaksi opsional, umpan balik), dan pengalaman bekerja (sikap kelompok, ketergantungan organisasi, impor pribadi) (Steers, 1977).

Tabel 4. Tabel Uji Hipotesis

\begin{tabular}{lrrr}
\hline & Original Sample $(\mathrm{O})$ & T Statistics $(|\mathrm{O} / \mathrm{STDEV}|)$ & $\mathrm{P}$ Values \\
\hline $\mathrm{SAW} \rightarrow \mathrm{AC}$ & 0.652 & 8.014 & $\mathbf{0 . 0 0 0}$ \\
$\mathrm{SAW} \rightarrow \mathrm{CC}$ & 0.488 & 6.667 & $\mathbf{0 . 0 0 0}$ \\
$\mathrm{SAW} \rightarrow \mathrm{NC}$ & 0.470 & 4.556 & $\mathbf{0 . 0 0 0}$ \\
\hline
\end{tabular}

1. Pada uji hipotesis pertama didapatkan nilai $P$ value sebesar $0.000<0.05$ artinya bahwa SAW memiliki pengaruh yang signifikan terhadap AC.

2. Pada uji hipotesis pertama didapatkan nilai $P$ value sebesar $0.000<0.05$ artinya bahwa 
SAW memiliki pengaruh yang signifikan terhadap CC.

3. Pada uji hipotesis pertama didapatkan nilai $P$ value sebesar $0.000<0.05$ artinya bahwa

SAW memiliki pengaruh yang signifikan terhadap NC.

Dari uji SEM yang dilakukan didapatkan hasil bahwa spirit at work berpengaruh secara positif dan signifikan terhadap komitmen afektif yang artinya semakin tinggi spirit at work yang dimiliki, maka semakin tinggi pula komitmen afektif yang dimiliki oleh guru honorer di $\mathrm{X}$ tersebut dan juga sebaliknya jika spirit at work semakin rendah, maka komitmen afektif yang dimilikipun akan semakin rendah.

Hasil yang didapatkan dari pengujian tersebut sesuai dengan hipotesis yang diajukan dalam penelitian ini, yaitu terdapat pengaruh yang signifikan antara spirit at work terhadap komitmen afektif, kontinuans, dan normatif guru honorer X. Dengan demikian, spirit at work memiliki pengaruh terhadap komitmen afektif, kontinuans, dan normatif di mana spirit at work memberikan pengaruh yang lebih banyak terhadap komitmen afektif dan memberikan pengaruh paling sedikit terhadap komitmen normatif. Dengan demikian, keempat hipotesis dalam penelitian ini diterima.

\section{Kesimpulan}

Berdasarkan pembahasan dalam penelitian ini, peneliti menyimpulkan beberapa hasil penelitian sebagai berikut:

1. Sebanyak 38 orang atau $95 \%$ guru honorer di X memiliki Spirit At Work yang tinggi.

2. Profil komitmen organisasi yang paling banyak dimiliki oleh guru honorer $\mathbf{X}$ adalah komitmen afektif, kontinuans, dan normatif yang seluruhnya tinggi dengan persentasi $75 \%$ atau sebanyak 30 orang yang memiliki profil tersebut.

3. Spirit at work secara simultan berpengaruh signifikan terhadap komitmen afektif $(0.000<0.05)$, komitmen kontinuans $(0.000<0.05)$, dan komitmen normatif $(0.000<0.05)$ dengan besar pengaruh antara spirit at work terhadap komitmen afektif sebesar $42.5 \%$, terhadap komitmen kontinuans sebesar $23.8 \%$, dan terhadap komitmen normatif sebesar $22.1 \%$.

\section{Ucapan Terimakasih}

Alhamdulillahirabbil 'alamiin, dengan memanjatkan puji serta syukur kepada Allah SWT karena atas rahmat dan hidayah-Nya penulis dapat menyelesaikan penulisan dan penyusunan skripsi ini untuk mendapatkan gelar sarjana. Penulis ingin mengucapkan terima kasih kepada Ali Mubarak S. Psi selaku pembimbing selama penyusunan penelitian skripsi ini, guru honorer $\mathrm{X}$ selaku responden dalam penelitian ini, kepada keluarga, teman-teman, serta pihak lainnya yang tidak dapat disebutkan satu per satu yang telah membantu dalam penyelesaian penelitian ini.

\section{Daftar Pustaka}

[1] Allen, N. J., \& Meyer, J. P. (1990). The measurement and antecedents of affective, continuance and normative commitment to the organization. Journal of occupational psychology, 63(1), 1-18.

[2] Allen, N. J., \& Meyer, J. P. (1996). Affective, continuance, and normative commitment to the organization: An examination of construct validity. Journal of vocational behavior, 49(3), 252-276.

[3] Ashmos, D. P., \& Duchon, D. (2000). Spirituality at work: A conceptualization and measure. Journal of management inquiry, 9(2), 134-145.

[4] Balkis, A. S., \& Masykur, A. M. (2017). Memahami subjective well-being guru honorer sekolah dasar negeri (sebuah studi kualitatif fenomenologis). Jurnal Empati, 5(2), 223228. 
[5] Bell-Ellis, R. S., Jones, L., Longstreth, M., \& Neal, J. (2015). Spirit at work in faculty and staff organizational commitment. Journal of Management, Spirituality \& Religion, 12(2), 156-177.

[6] Buchanan, B. (1974). Government managers, business executives, and organizational commitment. Public Administration Review, 339-347.

[7] CNN Indonesia. (2020). Kemendikbud: sekolah kekurangan 1 juta guru hingga 2024. Diakses pada https://www.cnnindonesia.com/nasional/20201005180513-20554645/kemendikbud-sekolah-kekurangan-1-juta-guru-hingga-2024

[8] Dewi, Retia Kartika. (2020). Daftar UMP 34 Provinsi di Indonesia, dari yang Terendah hinggi Tertinggi. Diakses pada https://www.kompas.com/tren/read/2020/10/29/190500065/daftar-ump-34-provinsi-diindonesia-dari-yang-terendah-hingga-tertinggi?page=all

[9] Duchon, D., \& Plowman, D. A. (2005). Nurturing the spirit at work: Impact on work unit performance. The leadership quarterly, 16(5), 807-833.

[10] Fitria, S., \& Nio, S. R. (2020). Kepuasan Kerja dan Loyalitas Kerja pada Guru Honorer SMA Swasta Bukittinggi. Proyeksi: Jurnal Proyeksi, 15(2), 131-140.

[11] Freund, A., Yahav, R., \& Gilboa-Arama, B. (2016). Workplace spirituality in social services departments. Journal of Religion \& Spirituality in Social Work: Social Thought, 35(3), 245-262.

[12] Gunawan, L. R., \& Hendriani, W. (2020). Psychological Well-being pada Guru Honorer di Indonesia: A Literature Review. Psikoislamedia: Jurnal Psikologi, 4(1), 105-113.

[13] Hairunnisa, I., \& Dirdjo, M. M. (2020). Hubungan Spiritualitas di Tempat Kerja dengan Komitmen Organisasi Perawat di RSJD Atma Husada Mahakam Samarinda. Borneo Student Research (BSR), 1(3), 1525-1530.

[14] JabarEkspres.com. (2019). Angka Guru Honorer di Bandung Masih Tinggi. Diakses pada https://jabarekspres.com/berita/2019/11/15/angka-guru-honorer-di-bandung-masihtinggi/

[15] Jafri, M. H., \& Lhamo, T. (2013). Organizational commitment and work performance in regular and contract faculties of Royal University of Bhutan. Journal of Contemporary Research in Management, 8(2), 47.

[16] Kinjerski, V. M., \& Skrypnek, B. J. (2004). Defining spirit at work: Finding common ground. Journal of organizational change management.

[17] Kinjerski, V., \& Skrypnek, B. J. (2006, August). MEASURING THE INTANGIBLE: DEVELOPMENT OF THE SPIRIT AT WORK SCALE. In Academy of management proceedings (Vol. 2006, No. 1, pp. A1-A6). Briarcliff Manor, NY 10510: Academy of Management.

[18] Kinjerski, V. A. L., \& Skrypnek, B. J. (2006). A human ecological model of spirit at work. Journal of management, Spirituality \& religion, 3(3), 231-241.

[19] Kinjerski, V., \& Skrypnek, B. J. (2008). The promise of spirit at workincreasing job satisfaction and organizational commitment and reducing turnover and absenteeism in long-term care. Journal of gerontological nursing, 34(10), 17-25.

[20] Mariana, L., Ramadhan, Y. A., \& Mariskha, S. E. (2019). Hubungan kebersyukuran dan komitmen organisasi pada guru honorer di kota Samarinda. MOTIVA JURNAL PSIKOLOGI, 1(2), 42-48.

[21] Meyer, J. P., \& Allen, N. J. (1991). A three-component conceptualization of organizational commitment. Human resource management review, 1(1), 61-89.

[22] Milliman, J., Czaplewski, A. J., \& Ferguson, J. (2003). Workplace spirituality and employee work attitudes: An exploratory empirical assessment. Journal of organizational change management, 16(4), 426-447.

[23] Mowday, R. T., Steers, R. M., \& Porter, L. W. (1979). The measurement of organizational commitment. Journal of vocational behavior, 14(2), 224-247. 
[24] Nastasia, K. (2019). HUBUNGAN KOMITMEN ORGANISASI DENGAN KINERJA PADA GURU PENDIDIK KHUSUS HONORER (GPK) DI KOTA PADANG. Psyche 165 Journal, 12(2), 174-182.

[25] Petchsawang, P., \& Duchon, D. (2009). Measuring workplace spirituality in an Asian context. Human resource development international, 12(4), 459-468.

[26] Petchsawang, P., \& Duchon, D. (2012). Workplace spirituality, meditation, and work performance. Journal of management, spirituality \& religion, 9(2), 189-208.

[27] Prakoso, A. R., Susilo, H., \& Nurlaily, E. K. (2018). Pengaruh Spiritualitas di Tempat Kerja (Workplace Spirituality) Terhadap Komitmen Organisasional (Studi pada Karyawan PT. Bank BRI Syariah Kantor Cabang Malang Soekarno Hatta). Jurnal Administrasi Bisnis, 65(1), 1-8.

[28] Rachmawati. (2021). Cerita Para Guru Honorer, Dilema antara Gaji Rendah dan Pengabdian Tanpa Kepastian. Diakses pada https://regional.kompas.com/read/2021/02/22/11010081/cerita-para-guru-honorerdilema-antara-gaji-rendah-dan-pengabdian-tanpa?page $=1$

[29] Robbins, Stephen P. \& Timothy A. Judge. (2017). Organizational behavior edition 17 global edition. England: Pearson Education Limited.

[30] Seniati, L. (2010). Pengaruh masa kerja, trait kepribadian, kepuasan kerja, dan iklim psikologis terhadap komitmen dosen pada Universitas Indonesia. Hubs-Asia, 10(1).

[31] Shani, Rhobi. (2018). Guru, beda status beda gaji. Diakses pada https://nusantara.medcom.id/jawa-tengah/peristiwa-jateng/0k8ZLwdN-guru-bedastatus-beda-gaji

[32] Silalahi, Ulber. (2017). Metode Penelitian Sosial Kuantitatif. Bandung: PT Refika Aditama.

[33] SMA BPI 1 Bandung. Sejarah SMA BPI. Diakses pada https://www.smasbpi1bdg.sch.id/page/sejarah

[34] Steers, R. M. (1977). Antecedents and outcomes of organizational commitment. Administrative science quarterly, 46-56.

[35] Sugiyono. (2013). Metode penelitian kuantitatif, kualitatif, dan r\&d. Bandung: Penerbit Alfabeta.

[36] Ufaira, R. A., \& Hendriani, W. (2020). MOTIVASI KERJA PADA GURU HONORER DI INDONESIA: A LITERATURE REVIEW. Psikoislamedia: Jurnal Psikologi, 4(2), 212221.

[37] Umam, M. R. K., \& Auliya, Z. F. (2018). Hubungan Kausalitas Workplace Spirituality Dan Kinerja Karyawan: Perspektif Mediasi Etika Kerja Islam. BISNIS: Jurnal Bisnis dan Manajemen Islam, 5(1), 23-50.

[38] Wahyuni, S. (2019). Meaningful Work, Kepemimpinan Transformasional dan Komitmen Organisasi Guru (Doctoral dissertation, Untag 1945 Surabaya).

[39] Yusnita, M. (2015). Pengaruh masa kerja dan kepuasan kerja terhadap komitmen organisasi guru honor (Studi Kasus pada SMA Unggulan di Kota Palembang). Holistic Journal of Management Research, 3(2), 65-78. 